\title{
Fair Value Measurement in Financial Reporting"
}

\author{
Dana DVǑ́ÁKOVÁ*
}

\section{Introduction}

This paper is an analytical study based on comparison of different approaches to fair value. The concept of the fair value measurement has been requested in a growing number of IFRS standards within last twenty years. Fair value was firstly defined in 1982 in IAS 20, but within the E.U. directive it has been allowed since 2001. The fair value measurement has not always been used consistently.

The defining fair value concept was processed many years. It was necessary to conceptually unify the use of fair value in the various IFRSs and also to unify the approaches to fair value in IFRS and U.S. GAAP (the process of convergence). The FASB issued SFAS 157 in the late 2006, followed by SFAS 159 in early 2007. The result of the convergence process was IASB (2006) draft "Fair Value Measurements (Part 1 and Part 2)" in November 2006, having the American standard as a source of inspiration and on 13th May 2011 the IFRS 13 - Fair Value Measurement was adopted (with the effective date 1st January 2013).

The project of the IASB and the FASB to develop a joint conceptual framework started by the Discussion Paper: Measurement Bases for Financial Accounting-measurement on Initial Recognition (IASB 2005), prepared by the staff of the Canadian Accounting Standards Board. This paper proposed the unprecedented extension of the use of fair value from the first recognition of an asset or liability. The material was apparently so controversial that his ideas were not further developed. The IASB in

\footnotetext{
\# This paper was prepared in the framework of research plan Development of Accounting and Financial Theory and its Application in Practice from Interdisciplinary Point of View (registered number MSM 6138439903).

Doc. Ing. Dana Dvořáková, Ph.D. - docent; Department of Financial Accounting and Auditing, Faculty of Finance and Accounting, University of Economics, Prague, W. Churchill Sq. 4, 13067 Prague, Czech Republic; 〈ddvorak@vse.cz>.
} 
cooperation with the FASB devoted issues to unify the approach to the measurement of fair value, but not the further spread of the use of fair value.

This paper aims to evaluate the existing development in the use of the fair value measurement and assessment of the benefits of the new IFRS 13 in this context.

\section{Literature Review}

A lot of research has been dealing with the fair value measurement in financial accounting. The Journal of Accounting Research takes the first place, having the highest number of published papers on fair value, and maintaining constant preoccupation in this field through the considered periods 2005-2009 (Bonaci - Matis - Strouhal, 2010). This can also be explained by the activities developed by the regulatory setting bodies, FASB and IASB (see introduction).

Fair value measurement for financial instruments reporting still seems to raise the highest interest; this field of financial instruments is favourable for both empirical and theoretical studies. (Danbold - Rees, 2008 p. 280) approached the British real estate and investment fund industries as experimental settings in order to show that fair value accounting for their real estate sample is considerably less value relevant than for the investment companies. Ronen (2008) and Wittington (2008) have theoretically analysed advantages and disadvantages of fair value.

When considering studies approaching the general concept of fair value, the majority is again in favour. Still, theoretical research has the highest rejection degrees of fair value accounting within the general category of studies dealing with the concept of fair value. As for these 'against studies', they mainly comprised new approaches and innovative ideas for the concepts that in the authors' view could help overcome fair value's drawbacks, but which of course have their own ones. In the category of the studies approaching the fair value of other specific elements, we also have a higher number of pros than cons, but most of the studies proved to be neutral. The general category of studies had a growing tendency for 'against studies', but this also is more explained through the Abacus 2008 special issue that stimulated a series of debates at the conceptual level of fair value, coming up with a series of new approaches of authors that suggested the replacement of fair value 
(Ronen, 2008, and Wittington, 2010). Ryan (2008) directly addresses the financial crisis and even if he discusses the critical aspects of SFAS 157's fair value definition and measurement guidance and explains the practical difficulties that have arisen in applying this definition and guidance to subprime positions during the crisis, together with raising a potential issue regarding the application of SFAS 159 of fair value option, makes it clear that fair value does not, and moreover could not, represent the root of the current, or any other potential financial crisis (Strouhal - Bonaci Mattis, 2011).

Currently there are not only fair value issues, but also the use of different measurement bases than fair value, being discussed. E.g. Dean (Dean) discussed issues concerning the use of exit value; Lennard (2010) dealt with entry value and Macve (2010) with deprival value issues.

\section{Methodology}

This paper is based on the comparative analysis of developments in the use of fair value measurement in the context of the measurement concept in financial accounting.

The starting point of this research is the formulation of the criteria for evaluation of the measurement bases. The next step of this research is the analysis of the current fair value measurement approaches in the particular IFRSs and the analysis of the impact of the newly adopted IFRS 13 on the fair value measurement approach in the particular IFRSs. This impact is evaluated on the basis of the criteria defined for the evaluation of the measurement bases.

\section{Fair Value Measurement before Adoption of IFRS 13}

\section{Fair value definition}

Fair value was firstly defined in 1982 within IAS 20. The definition was nearly identical with the definition introduced in the glossary of terms of the IASB Standards: "Fair value - The amount for which an asset could be exchanged, or a liability settled, between knowledgeable, willing parties in an arm's length transaction." IAS' Conceptual Framework established in 1989 did not introduce fair value, though it was used in particular standards. The Framework introduced historical cost, 
current cost, realisable value and present value. Current cost and realisable value are aimed at present conditions on the market. Current cost (replacement cost) expresses the position of a buyer (enter price) and the realisable value position of a seller (exit price). The Framework indicated that the included measurement bases might be and are combined in financial statements and stated that historical cost is the most commonly used measurement basis in financial statements and that the current cost basis is used as a response to the inability of the historical cost accounting model to deal with the effects of changing prices of nonmonetary assets.

The framework was partially amended in 2010 but the section on valuation remained unchanged. The text of the framework thus far indicates that the system of valuation under IFRS is based on the mixed measurement approach. It is also clear that the measurement bases in the framework reflect the entity-specific measurement. Otherwise, it is in individual standards which often require the fair value use.

Currently, the fair value definition is introduced in particular standards as follows: "Fair value - the amount for which an asset could be exchanged, or a liability settled, between knowledgeable, willing parties in an arm's length transaction." This measurement is not based on the actual market price.

Fair value is not the individual market value of an asset. Fair value is not a price obtainable in a particularly realized transaction. Fair value is the price concluded between free parties without any compulsion between subjects on the market. The rational motive of such a transaction is the profit of both parties. Therefore, the fair value measurement is based on the market measurement objective. It is not specified if the acquirable amount is from the view of a buyer, or a seller.

Theoretically there can be three versions:

- it can be the price from buyers point of view (entry price); or

- it can be the price from sellers point of view (exit price).

Particular standards can specify this view. There is a question if IFRSs will generally specify this point of view could the accounting information be more relevant and comparable? I suppose so. 
There is a problem how to achieve:

- a unified approach to the fair value measurement; and

- such asset's measurement which will express expected economic benefits from the asset in a particular enterprise.

The fair value measurement should be a valuation which as best as possible reflects current prices on an active market by arm's length transaction and simultaneously relevantly informs on assets in a certain enterprise.

If the active market is not developed enough, some Standards explicitly enable to use the present value measurement basis for fair value determination. The Standards analytically dealing with the fair value assessment offer, in most cases, the following possibilities:

- primary measurement basis- current prices on an active market;

- if an active market does not exist, an enterprise uses one or more of the following, determining fair value:

- The most recent market transaction price, provided that there has not been a significant change in economic circumstances between the date of that transaction and the balance sheet date.

- Market prices for similar assets with adjustment to reflect differences.

- Present value of expected discounted net cash flows from the asset.

- Particular Standards can introduce another means of fair value determination in accordance with particularity of theirs area.

\section{Fair value Application in Particular Standards}

The fair value measurement should be a valuation which as best as possible reflects current prices on an active market by arm's length transaction. The prime aim of the fair value measurement is to determine "non historical basis", to minimize risks of manipulation with the current cost measurement and to ensure the comparability and reliability of such measurement. This aim seems not to have been achieved in some standards. There are a lot of differences in the fair value measurement application in particular standards firstly in the areas as follow: 
- the desired or optional application of fair value measurement,

- fair value measurement only on the balance sheet date or also on initial recognition,

- guidance about how to measure fair value (a part of the standards uses the fair value measurement, but does not specify its determination),

- the impact of fair value revaluation (profit/loss, or other comprehensive income),

- the approach to transaction costs.

The standards using fair value for measurement of assets or liabilities can be divided roughly into three categories:

- Standards using fair value as an alternative treatment to historical cost

- Standards preferring or requesting the fair value measurement at each balance sheet date

- Standards requesting the fair value measurement on initial recognition and at each balance sheet date

Most standards use both fair value and historical cost. These standards usually use measurement at cost on initial recognition and historical cost or fair value measurement upon the balance sheet date (e.g. IAS 16, IAS $38)$.

IAS 16 - Property, Plant and Equipment introduces that items of property, plant or equipment can be carried at historical cost or at a revalued amount, being its fair value at the date of the revaluation less any subsequent accumulated depreciation and subsequent accumulated impairment losses. Revaluations should be made with sufficient regularity such that the carrying amount does not differ materially from that which would be determined using fair value at the balance sheet date. The fair value of land and buildings and equipment is usually its market value. This value is determined by appraisal normally undertaken by professionally qualified valuers.

Measurement in IAS 38 - Intangible assets is similarly as in IAS 16. After initial recognition, an intangible asset should be carried at its historical cost less any accumulated amortisation and any accumulated impairment losses or at fair value. For the purpose of revaluations under this Standard, fair value should be determined by reference to an active 
market. The Standard stresses that revaluations should be made with sufficient reliability. It is reasonable if we take into account the particularities of these assets.

The remeasurement in IAS 16 and IAS 38 will prevent the undervaluation of depreciation and the disclosure of overvaluation profit. This approach allows physical capital maintenance. Both Standards require application of IAS 36 - Impairment of Assets.

Some standards prefer or request the fair value measurement upon the balance sheet date (e.g. IAS 40) and some standards request fair value measurement upon initial recognition and upon the balance sheet date (e.g. IAS 39/IFRS 9, IAS 41).

Using fair value is preferred in IAS 40 - Investment Property (2000). An investment property should be measured initially at its cost. An enterprise should choose either the fair value model or the cost model as its accounting policy and should apply that policy to all of its investment property at balance sheet date. Change in accounting policy should be made only if the change will result in a more appropriate presentation of events or transactions in the financial statements of the enterprise. It is highly unlikely (according to IAS 40) that a change from the fair value model to the cost model will result in a more appropriate presentation. If an enterprise chooses the historical cost model, for the purpose of assets measurement in the balance sheet, fair value of assets must be disclosure. The fair value of investment property is usually its most probable market price reasonably obtainable at the balance sheet date. It is the best price reasonably obtainable by the seller and the most advantageous price reasonably obtainable by the buyer. The Standard recommended, but not required, to determine the fair value of investment property on the basis of a valuation by an independent valuer. An enterprise determines fair value without any deduction for transaction costs that the enterprise may incur on sale or other disposal. The Standard stresses to necessity to observe fair value's definition, especially the condition of knowledgeable, willing, independent parties. It has not to be the price obtainable in atypical circumstances, by compulsion or stringency.

IFRS 9 - Financial instruments (IAS 39) requests the fair value measurement on initial recognition and at balance sheet day. A financial asset shall be measured at amortised cost only if both of the following conditions are met: 
- The asset is held within a business model whose objective is to hold assets in order to collect contractual cash flows.

- The contractual terms of the financial asset give rise on specified dates to cash flows that are solely payments of principal and interest on the principal amount outstanding.

IAS 41 - Agriculture requests measurement of a biological asset and agricultural produce already on initial recognition and at each balance sheet date at its fair value less estimated point-of-sale costs. IAS 41 develops a detailed method of fair value's assessment as well as the disclosure of gain or loss arising in the fair value measurement.

If an active market exists for a biological asset or agricultural produce, the quoted price in that market is the appropriate basis for determining the fair value of that asset. If an enterprise has access to different active markets, the enterprise uses the most relevant one. If an active market does not exist, an enterprise uses in determining fair value: the most recent market transaction price, provided that there has not been a significant change in economic circumstances between the date of that transaction and the balance sheet date; market prices for similar assets with adjustment to reflect differences and sector benchmarks. In some circumstances, market-determined prices or values may not be available and an enterprise uses the present value of expected net cash flows from the asset discounted at a current market-determined pre-tax rate in determining fair value. These methods of the fair value measurement are in essence consistent with the methods used in other Standards. An important difference is that this Standard requires the fair value measurement of biological assets and harvested products at fair value less estimated the point-of-sale costs. The point-of-sale costs include commissions to brokers and dealers, levies by regulatory agencies and commodity exchanges, and transfer taxes and duties.

The fair value is the price in the relevant market less the transport and other costs of getting the asset to that market. The fair value is determined here as a market price with the deduction of all transaction costs. Such assessment lines up the fair value to the realisable value defined in the Framework, or to the net realisable value that is defined in IAS 2 Inventories in the following way: "Net realisable value is the estimated selling price in the ordinary course of business less the estimated costs of completion and the estimated costs necessary to make the sale." The important difference between these measurement bases is that the fair 
value in IAS 41 is based on the fair value definition; it means that the base for measurement is not an obtainable price from the enterprise's point of view but the current market price. Another important difference is that carrying amount of inventories can be only lower. However, inventories should be measured at the lower of cost and net realisable value on the principle of prudence.

All standards use market prices in active markets or the most recent market transaction price if there has not been a significant change in economic circumstances or the market price of comparable assets with an adjustment reflecting differences or the present value of the expected discounted net cash flows from the asset. Particular standards can introduce another means of fair value determination in accordance with the particularity of their area. No hierarchy exists for the application of these approaches.

The key issue of fair value measurement is the reporting of gains. There are different approaches used for the presentation of gains or losses from fair value changes:

- The revaluation model

- The model when the revaluation affects the result (through profit or loss)

- The model in which the revaluation does not affect profit or loss but other comprehensive income (through other comprehensive income)

In the revaluation model if an assets' carrying value is increased as a result of a revaluation, the increase shall be recognised in other comprehensive income. However, the increase shall be recognised in profit or loss to the extent that it reverses a revaluation decrease of the same asset previously recognised in profit or loss. The revaluation model is used for the revaluation of tangible assets for use by the entity (IAS 16) and intangible assets (IAS 38) as an alternative to the historical cost measurement. Based on the new measurement of fixed assets, the depreciation is newly set, which the entity will record for these assets. If there is an increase in the asset value, it consequently means an increase in depreciation in the subsequent years. The profit is reduced through depreciation at a level which corresponds to the value that will be necessary to restore the asset at the end of its useful life. So the 
revaluation of fixed assets in this case does not allow the distribution of unrealized holding gains to the owners.

In the "fair value through profit or loss" model, revaluation will always affect the net profit. Increasing the value of assets /gain/ will increase the profit and decreasing the asset value will reduce the profit. This model is used in IAS 40, IAS 41 and IFRS 9 (as well as within IAS 39).

In the "fair value through other comprehensive income" model, the revaluation of assets does not affect the profit, but the revaluation surplus which is created for this purpose in equity. Treating the impact of revaluation at fair value to the revaluation surplus causes the fact that the revaluation will not increase the reported profit by the possible unrealized gains and in this case, shares in the profit (dividends) from the results of the revaluation cannot be paid to the owners. Investments in equity instruments shall present accounting unit measure at fair value and subsequent changes in the fair value in other comprehensive income (IFRS 9).

\section{Changes in Fair Value Measurement after IFRS 13 Adoption}

IFRS 13 - Fair value measurement was adopted in May 2011. The IFRS 13 applies to standards that require or permit fair value measurements or disclosures about fair value measurements including the application of fair value under specific circumstances (such as fair value less costs to sell e.g. in IFRS 5), except in IFRS 13 specified cases. The aim of this standard is to explain how to measure fair value. Some of the IFRSs contained limited guidance about how to measure fair value (particular standards established earlier). Other standards contained extensive guidance and that guidance was not always consistent across those IFRSs that refer to fair value (see the analysis above).

IFRS 13 does not deal with the fact when fair value measurement should be or can be applied. This problem is solved in different standards (see examples above) and the requirements of these standards thus remain unchanged. From the above-mentioned differences in the application of fair value (see part 4.2), IFRS 13 may therefore unify in particular:

- guidance about how to measure fair value, and

- approach to transaction costs. 


\section{Fair Value Definition}

IFRS 13 defines fair value as the price that would be received to sell an asset or paid to transfer a liability in an orderly transaction between market participants at the measurement date (i.e. an exit price).

Also, this definition of fair value emphasises that fair value is a market-based measurement, not an entity-specific measurement.

This definition in fact states that fair value should be determined as the exit price, so from the perspective of the seller. This clarification unifies the approaches to fair value determining, but may bring certain risks in some situations.

Fair value calculation can be based theoretically either on the entry price or on the exit price. Assuming a perfectly functioning market, these prices shall be - this situation may arise in financial instruments traded in active markets. The prices at the market in which the trader buys and the market in which the trader sells, are different (depending on the gross profit margin). In such case, fair value defined as the entry price will be different from the fair value defined as the exit price.

IFRS 13 rather deals with the subsequent measurement at fair value and defines fair value as the exit price. But IFRS 13 applies both to the initial and subsequent measurement. When using the fair value measurement upon initial recognition, it makes sense to base the measurement of non-financial assets on the entry price at an (if possible) active, to the entity relevant market. The use of the exit price for nonfinancial assets would mean to measure including the anticipated sales margin, which is very risky. Currently the use of fair value is required upon initial recognition especially by IFRS and only for financial instruments, biological assets, and agricultural production.

\section{Fair Value Application}

The measurement techniques used in IFRS 13 should maximise the use of relevant observable inputs and minimise unobservable inputs.

The clear benefit of standard is specification of fair value determination in the following areas: 
- measurement object,

- market which is used to determine the fair value,

- transaction costs,

- fair value hierarchy.

IFRS 13 firstly determines that the object of measurement could be a stand-alone asset or liability; a group of assets; a group of liabilities; or a group of assets and liabilities (e.g. a cash-generating unit or a business). This possibility is introduced only in current standards IFRS 5 or IAS 36.

A fair value measurement assumes that the transaction to sell the asset or transfer the liability takes place either in the principal market or in the most advantageous market for the asset or liability. A definition of the principal market is a very important moment in IFRS 13 particularly with regard to the valuation of non-financial assets. This question has not been specified in any of the current standards. The problem arose mainly for biological assets and agricultural production measurement. If there is an active market price (e.g. a commodity exchange), an entity had to evaluate agricultural production based on exchange rates, regardless of whether it is able to realize the price in the market because of its current terms. Given that the prices of commodity exchanges were not available for the entity (realizable), the reporting of fictitious gains occurred.

The market price used to measure the fair value shall not be adjusted for transaction costs. Transaction costs do not include transport costs and if location is a characteristic of the asset (e.g. by tangible assets, inventories) the market price shall be adjusted for the cost.

To increase consistency and comparability in fair value measurements and related disclosures, IFRS 13 establishes a fair value hierarchy that categorises into three levels. Level 1 lies at the top of the hierarchy, where inputs are quoted prices in active markets. Level 2 inputs are in the middle of the hierarchy, where data are adjusted from similar items traded in active markets, or from identical or similar items in markets that are not active. Level 2 inputs do not stem directly from quoted prices. Level 3 inputs are unobservable and generated by the entity itself. An asset retirement obligation for an oil well, for example, would include expected risk-adjusted cash flows, using the company's own data. Another example of a Level 3 input is a financial forecast developed using the reporting entity's own data. 
Determining the fair value hierarchy is undoubtedly a step towards the unification of approaches to determine fair value, but it does not change the risk of fair value estimates. The risks associated with estimates of fair value when no active market price is available, are noted for example by Ronen (Ronen, 2008, p. 181): “... measures, derived as they are from current observed market prices, can be objectively determined and hence would meet the threshold of reliability... estimations of fair value based on predictable relationships among the observed input prices and the value of the asset or liability being measured. The degree of reliability one can attach to these derived measures would depend on the goodness of the fit between the observed input prices and the estimated value. Measurement errors and mis-specified models may compromise the precision of the derived estimates.... In the latter, unobservable inputs, subjectively determined by the firm's management, and subject to random errors and moral hazard, may cause significant distortions both in the balance sheet and in the income statement. Moreover, discounting cash flows to derive a fair value invites deception." This assessment is indeed very hard, but in many cases, particularly with regard to the practice, accurate.

On the other hand, it is also important to consider that... In many cases, an entity-specific measurement provides greater predictive information than market measurements that do not reflect specific managerial intentions and therefore the entity-specific measurement can be more relevant for the users of accounting information Smrčka (2009) stated: “...as based on my own auditing experiences of long ago-the following ideas are based on several behavioral premises: Information that is useful for and used by managers is more likely to be reliable than information that is only produced to satisfy external reporting requirements. However, this has to be tempered by the fear that management may manipulate data: hence bodies like the FASB/IASB seek 'objective statistics' (e.g., based on the original 'myth' of fair value derived from financial economics. It is important to triangulate management-prepared values against external market evidence wherever available - and especially now given recent experiences (post-2001) with Enron, WorldCom, etc., and even more recently, given the matters emerging in the aftermath of the GFC." The famous scandal of Enron is well documented also by Benston (2006, p. 466): "Enron used, to a large extent, level 3 and level 2 inputs for its external and internal reporting. Level 3 valuation was first used for energy contracts, then for trading activities generally and undertakings designated as 'merchant' 
investments, these fair values simultaneous being used to evaluate and compensate senior employees. As proven later, Enron's accountants (with Andersen's approval) used accounting devices to report cash flow from operations rather than financing and to otherwise cover up fair-value overstatements and losses on projects undertaken by managers whose compensation was based on fair values".

During the financial crisis, it can be doubted whether the measurement of fair value is more reliable and more relevant than the entity-specific measurement of not only non-financial assets but also of financial instruments. Ryan (2008, p. 183) states to it: "That said, the major question now is whether, in the current markets even the Level 1 FVs (NB.: Level $1 \mathrm{FVs}=$ market price for identical assets or liabilities which are readily available from active markets) are now reliable. It is worth contemplating this in the light of the recent developments regarding FASB's new FSP 157-4; and also FAS 115-2, FAS 124-2 regarding impairments."

\section{Conclusion}

The major benefit of the IFRS 13 is increasing the comparability and neutrality of accounting information, thereby increasing decision usefulness. Of course, the issue of reliability and verifiability of market information is still remaining, especially in terms of inactive markets. The determination of the fair value hierarchy prevents misusing the possibility of a free election of the measurement treatment and therefore prevents net profit manipulating. We can also positively evaluate the definition of the principal market, for example by issues of biological assets and agriculture production measurement. However, the use of fair value upon initial recognition defined as the exit price is conceptually wrong and risky.

\section{References}

[1] Bonaci, C. G. - Matis, D. - Strouhal, J. (2010): Fair Value and Crisis: Defense Welcomed, In.: Recent Advances in Management, Marketing, Finances. Penang, WSEAS, pp. 71-75. 
Dvořáková, D.: Fair Value Measurement in Financial Reporting.

[2] Benston, G. J. (2006): Fair-Value Accounting: A Cautionary Tale from Enron. Journal of Accounting and Public Policy, 2006, vol. 25, no. 4, pp. 465-484.

[3] Danbolt, J. - Rees, W. (2008): An Experiment in Fair Value Accounting: UK Investment Vehicles. European Accounting Review, 2008, vol. 17, no. 2, pp. 271-303.

[4] Dean, G. (2010): Background and Case for Exit Price Accounting. Abacus, 2010, vol. 46, no. 1, pp. 84-96.

[5] IASB (2005): Discussion paper Measurement Bases for Financial Accounting-measurement on Initial Recognition. London, IASCF, 2005.

[6] IASB (2006): Discussion Paper Fair Value Measurements Part 1: Invitation to Comment and relevant IFRS guidance. London, IASCF, 2006.

[7] Lennard, A. (2010): The Case for Entry Values: A Defence of Replacement Cost. Abacus, 2010, vol. 46, no. 1, pp. 97-103.

[8] Macve, R. (2010): The Case for Deprival Value. Abacus, 2010, vol. 46, no. 1, pp. 111-119.

[9] Ryan, S. G. (2008): Accounting in and for the Subprime Crisis. The Accounting Review, 2008, vol. 83, no. 6, pp. 1605-1638.

[10] Ronen, J. (2008): To Fair Value or Not to Fair Value: A Broader Perspective. Abacus, 2008, vol. 44, No. 2, pp. 181-208.

[11] Smrčka, L. (2009): How Did the Financial Crisis of 2008 Arise. [CD-ROM]. In: Academic Research Preoccupation in the Central and Eastern Europe. Bucuresti, Academiei de Studii Economice, 2009.

[12] Strouhal, J. - Bonaci, C. G. - Matis, E. A. (2011): Corporate governance Lesson Taught by the Financial Crisis: A Research Note. International Journal of Mathematical Models and Methods in Applied Sciences, 2011, vol. 5, no. 3, pp. 688-695.

[13] Whittington, G. (2008): Fair Value and the IASB/FASB Conceptual Framework Project: An Alternative View. Abacus, 2008, vol. 44, no. 2, pp. 139-168.

[14] Whittington, G. (2010): Measurement in Financial Reporting, Abacus, 2010, vol. 46, no. 1, pp. 104-110. 


\title{
Fair Value Measurement in Financial Reporting
}

\author{
Dana DVOŘÁKOVÁ
}

\begin{abstract}
Measurement in financial accounting has been the most discussed issue in recent decades. The last very important result of the convergence process between IFRS and U.S. GAAP was adopting IFRS 13 - Fair Value Measurement in May 2011. The objective of IFRS 13 is to unify the approaches to determining fair value under IFRSs. The aim of this paper is to offer a comprehensive evaluation of the pros and cons that this standard brings.
\end{abstract}

Key words: Measurement; Fair value; Historical cost; Accounting; Assets; Liabilities.

JEL classification: M41 